DOI: $10.25140 / 2411-5215-2021-1(25)-134-142$

\author{
Катерина Гнедіна, Павло Нагорний
}

\title{
ЗВІТ ПРО УПРАВЛІННЯ: СУТНІСТЬ ТА ОСОБЛИВОСТІ ФОРМУВАННЯ
}

\section{Kateryna Hnedina, Pavlo Nahornyi \\ MANAGEMENT COMMENTARY: ESSENCE AND FEATURES OF FORMATION}

У статті здійснено огляд особливостей формування Звіту про управління. Визначено сутність Звіту про управління, наведено його характеристику в порівнянні з традиційною фінансовою звітністю, окреслено переваги та недоліки. Розглянуто Звіти про управління кількох украӥнських компаній та визначено сильні та слабкі сторони сформованих звітів. Наведено пропозииії стосовно розкриття у Звіті про управління інформачї щчодо соиіальних та екологічних аспектів діяльності підприємства.

Ключові слова: Звіт про управління; екологічна відповідальність; сочіальна відповідальність; ESG-звітність; інтегрована звітність; управлінський облік; управлінські рішення.

Рис.: 1. Табл.: 3. Бібл.: 17.

The peculiarities of the formation of the Management Commentary are reviewed in the article. The essence of the Management Commentary is determined, its characteristics in comparison with the traditional financial reporting are given, the advantages and disadvantages are defined. The Management Commentary of several Ukrainian companies are examined, the strengths and weaknesses of the generated reports are identified. Suggestions for disclosure of information concerning social and environmental aspects of the enterprise activity in the Management Commentary are described.

Keywords: Management Commentary, environmental responsibility, social responsibility, ESG-reporting, integrated reporting, management accounting, management decisions.

Fig.: 1. Table: 3. References: 17.

JEL Classification: M14; M21; M41; M48

Постановка проблеми. В умовах поширення концепції сталого розвитку та зростання вимог до соціальних та екологічних наслідків функціонування бізнесу особливої актуальності набуває відображення у звітності підприємств не лише фінансової інформації, а й нефінансової, яка розкриває різні аспекти діяльності суб'єктів господарювання та висвітлює політику управління соціально-екологічними ризиками, стратегію розвитку підприємства тощо. Це зумовлює появу та поширення нових форм звітності, яка надає повну та достовірну інформацію стейкхолдерам про всі аспекти діяльності підприємства, зокрема - Звіту про управління. Вітчизняні підприємства мають недостатній досвід складання та подання Звітів про управління, що позначається на рівні їх інформаційного наповнення. Саме тому актуальним та важливим є дослідження наявних вимог та підходів до формування Звіту про управління.

Аналіз останніх досліджень і публікацій. Звіт про управління є новою формою звітності для вітчизняних підприємств. Водночас дослідження процесу його формування перебуває в центрі уваги науковців. Висвітленню питань впровадження Звіту про управління, його переваг та недоліків, можливих шляхів вдосконалення присвячено наукові праці таких учених, як Т. Бондар, К. Безверхий, В. Пантелєєв, С. Свірко, О. Баришнікова, В. Царук, В. Онищенко, Н. Валькова, А. Костякова, П. Куцик, I. Захарчук, Н. Захарова, М. Уткіна, А. Басок, Ю. Слободяник та інших.

Виділення недосліджених частин загальної проблеми. Зважаючи на новизну Звіту про управління, досить багато питань щодо його формування залишаються недостатньо дослідженими. Зокрема, актуальними $є$ питання інформаційного наповнення Звіту про управління, визначення можливостей використання інформації, що містить цей звіт, у процесі прийняття управлінських рішень, а також забезпечення соціальної та екологічної відповідальності бізнесу. Крім того, доцільним є узагальнення досвіду формування відповідних звітів вітчизняними підприємствами з метою розробки пропозицій щодо вдосконалення змісту Звіту про управління.

Метою статті $є$ здійснення огляду особливостей складання Звіту про управління та наданні практичних рекомендацій щодо розкриття інформації у звіті стосовно різних аспектів діяльності підприємства з метою вдосконалення інформаційного забезпечення прийняття стратегічних управлінських рішень користувачами.

() Гнедіна К. В., Нагорний П. В., 2021 
ФІНАНСОВІ РЕСУРСИ: ПРОБЛЕМИ ФОРМУВАННЯ ТА ВИКОРИСТАННЯ

Виклад основного матеріалу. Звіт про управління - особлива форма звітності, яка подається великими та середніми підприємствами. У статті 1 Закону України «Про бухгалтерський облік та фінансову звітність в Україні» від 16 липня 1999 року [1] зазначено, що «Звіт про управління - документ, що містить фінансову та нефінансову інформацію, яка характеризує стан і перспективи розвитку підприємства та розкриває основні ризики i невизначеності його діяльності». Аналізуючи наведене визначення, можемо стверджувати, що така форма звітності, зважаючи на призначення, має певні обов'язкові структурні елементи. Відповідно до Методичних рекомендацій зі складання Звіту про управління № 982 [2] основними структурними елементами Звіту про управління $є$ : «Організаційна структура та опис діяльності підприємства», «Результати діяльності», «Ліквідність та зобов’язання», «Екологічні аспекти», «Соціальні аспекти та кадрова політика», «Ризики», «Дослідження та інновації», «Фінансові інвестиції», «Перспективи розвитку», «Корпоративне управління». Слід зазначити, що єдиної стандартизованої форми для Звіту про управління не визначено, адже це суперечило б самій ідеї цієї форми звітності, яка дозволяє у вільному порядку презентувати найбільш суттєві особливості діяльності підприємства. Методичними рекомендаціями [2] визначено лише пропозиції щодо основних структурних елементів цього звіту та розкриття інформації в них.

Зважаючи на наявність у структурі Звіту про управління складових «Екологічні аспекти», «Соціальні аспекти та кадрова політика» та «Корпоративне управління», можемо стверджувати, що ця форма звітності належить до ESG-statement - популярної у зарубіжних країнах звітності сталого розвитку [3]. Основна мета подання звітності сталого розвитку підтвердження слідування компанією світовому тренду дотримання принципів сталого розвитку, забезпечення прийнятних соціальних умов для працівників підприємства тощо. Звіт про управління за своїм змістом також належить до Integrated statement (інтегрованої звітності), адже передбачає відображення не тільки фінансової, а й нефінансової інформації [4]. Тому Звіт про управління не належить до фінансової звітності. Зазначимо, що часто саме нефінансова інформація займає значну частку Звіту про управління.

Якщо порівнювати Звіт про управління з традиційною фінансовою звітністю, то можна зауважити такі особливості: Звіт про управління, на відміну від фінансової звітності, включає нефінансову інформацію, не має стандартизованої форми, включає аналіз даних, коментарі, висновки, інфографіку для візуалізації даних, охоплює представлення не лише ретроспективної інформації, а і планів компанії на майбутнє тощо (табл. 1).

Таблиця 1

Порівняльна характеристика фінансової звітності та Звіту про управління

\begin{tabular}{|c|c|c|}
\hline Характеристика & Фінансова звітність & Звіт про управління \\
\hline $\begin{array}{c}\text { Відображення фінансових характери- } \\
\text { стик діяльності }\end{array}$ & & Наявне \\
\hline $\begin{array}{c}\text { Публікація на офіційних } \\
\text { інтернет-представництвах компанії }\end{array}$ & & Передбачена \\
\hline Стандартизований формат & Наявний & Відсутній \\
\hline Нефінансова інформація & Відсутня & Наявна \\
\hline Власний підхід до заповнення & Не передбачається & Передбачається \\
\hline $\begin{array}{l}\text { Сприяння поширенню соціальної та } \\
\text { екологічної відповідальності компаній }\end{array}$ & Відсутнє & Наявне \\
\hline Аналіз наведених даних, висновки & Не передбачається & Передбачається \\
\hline Форма вираження даних & Числова & Описова, числова, візуальна \\
\hline Часовий період даних & Минуле, теперішнє & Минуле, теперішнє, майбутнє \\
\hline Обов'язковість подання & Для всіх підприємства & Для великих та середніх підприємств \\
\hline $\begin{array}{c}\text { Адміністративна відповідальність за } \\
\text { порушення порядку подання }\end{array}$ & Передбачена & Не передбачена \\
\hline Подання в державні органи & $\begin{array}{c}\text { ДФС, Держстат, НБУ } \\
\text { (банки) }\end{array}$ & НКЦПФР, НБУ (банки) \\
\hline
\end{tabular}

Джерело: розроблено авторами на основі [5-7]. 
На міжнародному рівні рекомендації щодо складання Звіту про управління відображено у IFRS Practice Statement 1 Management Commentary (Положення з практики «Коментар керівництва») [8]. Напрями розкриття інформації у Звіті про управління відповідно до національних методичних рекомендацій та Положення 3 практики «Коментар керівництва» представлено на рис. 1.

Інформаційне наповнення Звіту про управління

$\xi$

Національний рівень: відповідно до Методичних рекомендацій зі складання

звіту про управління № 982 [2]

Звіт про управління

I «Організаційна структура та опис діяльності підп-
риємства» (Організаційна структура, стратегія та цілі,
сфера та характер діяльності підприємства, інформація
про продукцію (послуги), що виробляються (надаються)
$\begin{aligned} & \text { підприємством, ринкова частка в різних сегментах та } \\ & \text { ін.) }\end{aligned}$

II «Результати діяльності» (Аналіз результатів діяльності підприємства)

III «Ліквідність та зобов'язання» (Інформація про основні джерела забезпечення ліквідності, наявні зобов'язання, їх види та строки погашення, умовні зобов'язання, фактори впливу на ліквідність)

IV «Екологічні аспекти» (Інформація про вплив діяльності підприємства на навколишнє середовище, заходи 3 охорони довкілля)

V «Соціальні аспекти та кадрова політика» (Інформація про кількість працівників та частку жінок на керівних посадах, мотивацію, охорону праці та безпеку, навчання та освіту персоналу, повагу прав людини, заходи боротьби з корупцією тощо)

VI «Ризики» (Інформація про політику підприємства щодо управління ризиками, опис впливу ризиків на його діяльність та інструменти зменшення такого впливу)

VII «Дослідження та інновації» (Інформація про дослідження, інноваційну діяльність та розробки, які проводяться підприємством, обсяг витрат на такі заходи та їхній вплив на діяльність підприємства)

VIII «Фінансові інвестиції» (Інформація про фінансові інвестиції підприємства у цінні папери інших підприємств, фінансові інвестиції в асоційовані і дочірні підприємства)

IX «Перспективи розвитку» (Інформація про перспективи розвитку підприємства 3 урахуванням ризиків та викликів при здійсненні діяльності)

$\mathbf{X}$ «Корпоративне управління» (Інформація про органи управління, загальні збори акціонерів, структуру акціонерів та ін.)

\section{2}

Міжнародний рівень: відповідно до IFRS Practice Statement 1: Management Commentary

Положення з практики «Коментар керівництва» [8]

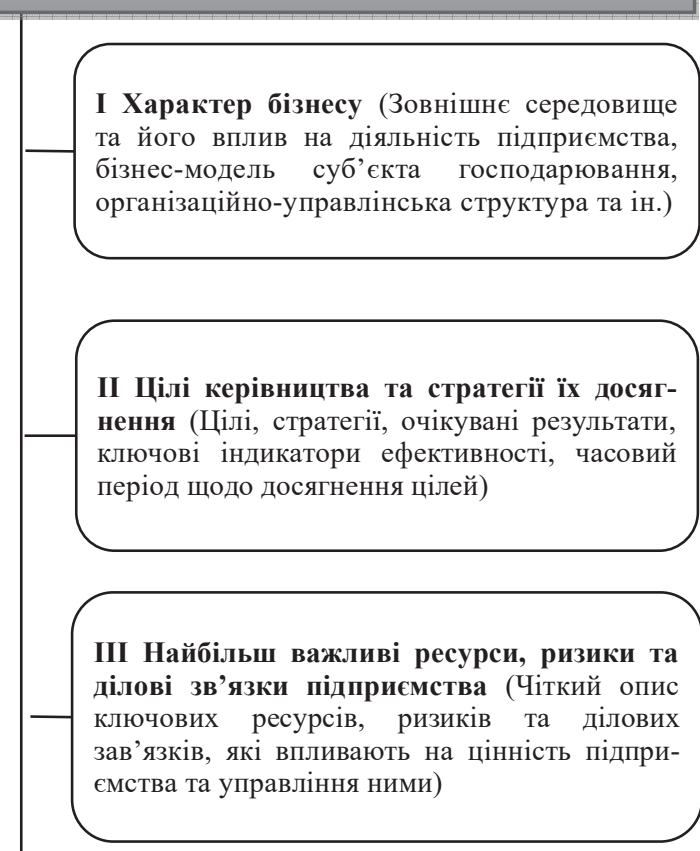

IV Результати діяльності та перспективи (Фінансові та нефінансові результати діяльності, плани підприємства на майбутне та оцінка керівництвом перспектив його розвитку)

V Ключові критерії ефективності та показники, які використовуються управлінським персоналом для оцінювання ефективності діяльності підприсмства в порівнянні 3 поставленими цілями (Ключові критерії та індикатори (фінансові та нефінансові), які використовуються для кількісного оцінювання результативності (ефективності) діяльності підприсмства та досягнення поставлений цілей)

\section{Рис. 1. Напрями розкриття інформації у Звіті про управління}

Джерело: [5, с. 81;2;8]. 
ФІНАНСОВІ РЕСУРСИ: ПРОБЛЕМИ ФОРМУВАННЯ ТА ВИКОРИСТАННЯ

Відповідно до Положення з практики «Коментар керівництва», яким керуються зарубіжні компанії при складанні Звіту про управління, основними компонентами такого звіту є: «Характер бізнесу», «Цілі керівництва та стратегії їх досягнення», «Найбільш важливі ресурси, ризики та ділові зв’язки підприємства», «Результати діяльності та перспективи», «Ключові критерії ефективності та показники, які використовуються управлінським персоналом для оцінювання ефективності діяльності підприємства у порівнянні із поставленими цілями» [8].

Отже, Звіт про управління є звітом, який містить інформацію про фінансові та нефінансові результати, ризики та перспективи діяльності підприємства і використовується стейкхолдерами для прийняття управлінських рішень, його форма та зміст залежать від специфіки діяльності підприємства, вимог внутрішніх і зовнішніх користувачів, підходів до його формування та визначаються підприємством самостійно з урахуванням чинних рекомендацій [5].

Особливу увагу при формуванні Звіту про управління слід звернути на висвітлення стратегічних планів розвитку підприємства та навести перелік ключових індикаторів успіху бізнесу, його ефективності. При цьому як результати, індикатори ефективності, так і плани діяльності мають стосуватися різних аспектів діяльності підприємства. Враховуючи необхідність дотримання підприємством концепції сталого розвитку, у Звіті про управління доцільно розкривати інформацію стосовно економічних, екологічних та соціальних результатів (наслідків) діяльності. Звіт про управління може виступати індикатором соціальної та екологічної відповідальності бізнесу, надаючи стейкхолдерам інформацію про соціальну та екологічну політики підприємства. До розкриття такої інформації слід підходити комплексно та наводити не лише опис умов праці, системи мотивації, соціального захисту працівників, реалізованих екологічних ініціатив та вплив на довкілля, а й конкретні показники, які б демонстрували результати діяльності підприємства у цих сферах. Зміст Звіту про управління не має дублювати зміст фінансової звітності. Звіт про управління має включати всебічну інформацію про діяльність підприємства для прийняття управлінських рішень користувачами.

Звіт про управління - ефективний інструмент поширення соціальної та екологічної відповідальності серед середніх та великих підприємств України. Водночас така форма звітності має свої переваги та недоліки, можливості та загрози (табл. 2).

Таблиця 2

\section{SWOT-аналіз 3віту про управління}

\begin{tabular}{|c|c|}
\hline Сильні сторони & Слабкі сторони \\
\hline $\begin{array}{l}\text { - Допустимість власного підходу, стилю оформлення; } \\
\text { - Відображення у звіті про управління комплексної } \\
\text { характеристики підприємства; } \\
\text { - Можливість оцінити ризики та стратегію компанії } \\
\text { роботи з ними; } \\
\text { - Звертання уваги не тільки на минуле, а й на май- } \\
\text { бутнє компанії; } \\
\text { - Публічність інформації, доступ до неї широкого } \\
\text { кола користувачів. }\end{array}$ & $\begin{array}{l}\text { - Невизначеність відповідальності за порушення } \\
\text { заповнення чи подання звіту про управління; } \\
\text { - Відсутність хоча б мінімальних вимог до напов- } \\
\text { неності звіту про управління; } \\
\text { - Відсутність достатнього досвіду формування ін- } \\
\text { тегрованої звітності у вітчизняних компаній, висві- } \\
\text { тлення у звіті нефінансової інформації; } \\
\text { - Складність порівняння звітів різних компаній. }\end{array}$ \\
\hline Можливості & 3ai \\
\hline $\begin{array}{l}\text { - Сприяння зростанню соціальної та екологічної } \\
\text { відповідальності серед компаній; } \\
\text { - Залучення додаткових інвесторів та кредиторів; } \\
\text { - Покращення іміджу компанії, підтримка сучасно- } \\
\text { го, соціально відповідального бренду; } \\
\text { - Можливість прослідкувати помилки бізнес- } \\
\text { моделі підприємства, окремих дій керівництва; } \\
\text { - Надання повної інформації щодо діяльності ком- } \\
\text { панії іноземним зацікавленим особам. }\end{array}$ & $\begin{array}{l}\text { - Приховування негативних відомостей щодо дія- } \\
\text { льності компанії та неподання відповідної інфор- } \\
\text { мації у звіті; } \\
\text { - Помилки при заповненні звіту про управління че- } \\
\text { рез відсутність досвіду заповнення подібних звітів; } \\
\text { - Сприймання компанією звіту про управління як } \\
\text { частини фінансової звітності та ігнорування бага- } \\
\text { тьох його можливостей. }\end{array}$ \\
\hline
\end{tabular}

Джерело: розроблено авторами. 
Проаналізувавши зміст Звітів про управління декількох вітчизняних підприємств [914], можемо зазначити, що підходи управлінського персоналу до складання Звіту про управління є різними. Окремі компанії надають перевагу зовсім коротким звітам, інші публікують великі за обсягом звіти. Можна виокремити такі основні підходи до формування Звіту про управління серед українських компаній:

- Включення до звіту майже всіх основних структурних елементів, зазначених у Методичних рекомендаціях [2]. Помірне висвітлення фінансових показників. Принцип розподілу інформації та відмови від дублювання даних у різних формах звітності. Висвітлення інформації про соціальну та екологічну відповідальності бізнесу. Активне використання візуалізації даних.

- Відсутність чіткого розуміння призначення звіту. Уподібнення традиційній фінансовій звітності. Відмова від використання візуалізації даних. Перевага словесної та числової форм даних. Переважання фінансової інформації над нефінансовою. Недостатня увага приділена висвітленню соціальних та екологічних аспектів діяльності підприємств. За умови застосування другого підходу Звіт про управління дублює великі обсяги фінансової інформації та втрачає свою лаконічність та чіткість.

Отже, у Звітах про управління вітчизняних підприємств доцільно більше уваги приділяти висвітленню соціальних та екологічних аспектів діяльності та наводити конкретні показники, рекомендований перелік яких представлено в табл. 3. Розкриття такої інформації у Звіті про управління сприятиме вдосконаленню інформаційного забезпечення прийняття управлінських рішень з метою покращення соціальних та екологічних результатів діяльності суб'єкта господарювання.

Таблиця 3

Пропозиції щуодо розкриття у Звіті про управління інформащії про сочіальні та екологічні аспекти діяльності підприємства

\begin{tabular}{|c|c|c|}
\hline $\begin{array}{c}\text { Складові Звіту } \\
\text { про управління }\end{array}$ & Питання, що висвітлюються & $\begin{array}{c}\text { Показники, які } \\
\text { доцільно навести }\end{array}$ \\
\hline 1 & 2 & 3 \\
\hline $\begin{array}{c}\text { Соиіальні аспекти } \\
\text { діяльності }\end{array}$ & $\begin{array}{l}\text { 1) Винагорода за працю. Інформація щодо розмірів вина- } \\
\text { городи за працю, її відповідності встановленим нормати- } \\
\text { вам, а також інформація про преміювання працівників. } \\
\text { 2) Нормативи відпочинку. Інформація про тривалість від- } \\
\text { пусток, вихідних, святкових тощо. } \\
\text { 3) Охорона здоров ’я. Відомості про лікарняні, регулярні } \\
\text { медичні огляди тощо. } \\
\text { 4) Шкідливість виробництва. Інформація про виробничу } \\
\text { діяльність, яка може шкодити здоров’ю працівників. } \\
\text { 5) Матеріальна підтримка. Інформація щодо всіх неви- } \\
\text { робничих виплат працівникам (підтримка багатодітних, } \\
\text { допомога у випадку народження дитини тощо). } \\
\text { 6) Інклюзивність. Відомості про підтримку працівників з } \\
\text { особливими потребами, що працюють на підприємстві. } \\
\text { 7) Культурно-освітні заходи. Інформація про культурно- } \\
\text { освітні заходи, які реалізовані для працівників підприємства. } \\
\text { 8) Корпоративна культура. Інформація про систему цін- } \\
\text { ностей підприємства, норм поведінки, етичні принципи, } \\
\text { яких дотримуються всі працівники підприємства тощо. }\end{array}$ & $\begin{array}{l}\text { 1) Середні обсяги за- } \\
\text { робітної плати різних } \\
\text { груп працівників. } \\
\text { 2) Обсяги премій та } \\
\text { інших матеріальних } \\
\text { виробничих заохочень. } \\
\text { 3) Частка працівників, } \\
\text { що проходять регуляр- } \\
\text { ні медичні огляди. } \\
\text { 4) Обсяги невиробни- } \\
\text { чої матеріальної допо- } \\
\text { моги працівникам. } \\
\text { 5) Кількість працівни- } \\
\text { ків з особливими пот- } \\
\text { ребами. } \\
\text { 6) Кількість та харак- } \\
\text { теристика культурно- } \\
\text { освітніх заходів для } \\
\text { робітників та ін. }\end{array}$ \\
\hline $\begin{array}{c}\text { Екологічні аспекти } \\
\text { діяльності }\end{array}$ & $\begin{array}{l}\text { 1) Забруднення атмосфери. Інформація про здійснення } \\
\text { підприємством викидів шкідливих речовин у атмосферу. } \\
\text { 2) Забруднення гідросфери. Інформація про забруднення } \\
\text { підприємством гідросфери. } \\
\text { 3) Тверді відходи. Інформація про утворення твердих від- } \\
\text { ходів. }\end{array}$ & $\begin{array}{l}\text { 1) Обсяги викидів в } \\
\text { атмосферу. } \\
\text { 2) Обсяги викидів у } \\
\text { гідросферу. } \\
\text { 3) Обсяги утворених } \\
\text { твердих відходів. } \\
\end{array}$ \\
\hline
\end{tabular}


Закінчення табл. 3

\begin{tabular}{|c|c|c|}
\hline 1 & 2 & 3 \\
\hline & $\begin{array}{l}\text { 4) Сортування відходів. Інформація про сортування від- } \\
\text { ходів підприємством. } \\
\text { 5) Хімічне забруднення. Інформація про хімічне забруд- } \\
\text { нення та шкідливий вплив на біосферу. } \\
\text { 6) Шумове забруднення. Інформація про шумове забруд- } \\
\text { нення. } \\
\text { 7) Теплове забруднення. Відомості про теплове забруд- } \\
\text { нення та негативний вплив на навколишнє середовище. } \\
\text { 8) Світлове забруднення. Інформація про штучну люмінес- } \\
\text { ценцію, яка негативно впливає на навколишнє середовище. } \\
\text { 9) Візуальне забруднення. Інформація про атрибути зов- } \\
\text { нішньої реклами, які здатні візуально перекривати есте- } \\
\text { тичні об'єкти. } \\
\text { 10) Екологічні заходи. Кількість проведених екологічних } \\
\text { заходів, опис реалізованих екологічних ініціатив тощо. } \\
\text { 11) Екологічна політика. Інформація про екологізацію } \\
\text { виробництва, впровадження екологічних технологій, ра- } \\
\text { ціональне використання природних ресурсів, забезпечен- } \\
\text { ня екологічної безпеки підприємства загалом та ін. }\end{array}$ & $\begin{array}{l}\text { 4) Обсяги утворених шкі- } \\
\text { дливих хімічних речовин. } \\
\text { 5) Середня гучність робо- } \\
\text { ти найбільших шумоутво- } \\
\text { рювачів. } \\
\text { 6) Обсяги утвореного теп- } \\
\text { ла (для окремих груп під- } \\
\text { приємств). } \\
\text { 7) Кількість атрибутів } \\
\text { зовнішньої реклами, бі- } \\
\text { льших за встановлений } \\
\text { розмір. } \\
\text { 8) Кількість та характери- } \\
\text { стика проведених екологі- } \\
\text { чних заходів. } \\
\text { 9) Екологічний податок, } \\
\text { сплачений підприємством. } \\
\text { 10) Екологічні витрати та } \\
\text { ін. }\end{array}$ \\
\hline
\end{tabular}

Джерело: розроблено авторами на основі [15-17].

Висновки і пропозиції. Проведене дослідження сутності та особливостей складання Звіту про управління дозволяє сформулювати такі висновки:

1. Звіт про управління - інноваційна форма звітності, що містить фінансову та нефінансову інформацію, яка характеризує діяльність підприємства та його плани на майбутнє. Ключовими відмінними рисами Звіту про управління у порівнянні з фінансовою звітністю є те, що у цьому розкриваються результати економічної, соціальної, екологічної діяльності підприємства, наводиться інформація про стратегічні напрями розвитку бізнесу, відсутня стандартизована форма тощо. До сильних сторін Звіту про управління можна віднести його комплексність, індивідуальність, високий ступінь деталізації інформації, охоплення всієї діяльності підприємства.

2. Результати огляду сформованих вітчизняними підприємствами Звітів про управління свідчать про те, що їхніми ключовими недоліками є: фокусування уваги лише на фінансових показниках компанії, відсутність опису інноваційної діяльності та управління потенційними ризиками, інформації щодо соціальної та екологічної відповідальності, інновацій, інвестицій, стратегії тощо. Часом має місце повне уподібнення традиційній фінансовій звітності без розкриття у Звіті про управління нефінансової інформації. Крім того, у певних Звітах про управління відсутня візуалізація наведених даних, що знижує їхню презентабельність. Недостатній досвід формування Звітів про управління вітчизняними підприємствами позначається на інформаційному наповненні таких звітів та втраті можливостей забезпечення користувачів повною інформацією про результати діяльності підприємства.

3. Звіт про управління покликаний надавати вичерпні відомості стейкхолдерам стосовно всіх аспектів діяльності підприємства, включати фінансову на нефінансову інформацію. Враховуючи значний потенціал використання Звіту про управління як інструменту підвищення соціальної та екологічної відповідальності бізнесу, особливу увагу при його формуванні треба приділити розкриттю інформації про соціальні та екологічні аспекти діяльності підприємства з наведенням конкретних показників. Такий підхід до формування Звіту про управління сприятиме забезпеченню користувачів звіту повною та вичерпною інформацією для прийняття ними управлінських рішень у сфері підвищення соціальної та екологічної ефективності діяльності суб'єкта господарювання. 


\section{Список використаних джерел}

1. Про бухгалтерський облік та фінансову звітність в Україні : Закон України від 16 липня 1999 р. № 996-XV. Відомості Верховної Ради Украӥни. 1999. № 40. Ст. 365.

2. Про затвердження Методичних рекомендацій зі складання звіту про управління : Наказ Міністерства фінансів України від 7 грудня 2018 р. № 982. Баланс. 2019. № 12-13. С. 10.

3. Свірко С. В., Баришнікова О. М. Звітність сталого розвитку як засіб відображення стану економіко-екологічної безпеки підприємства. Проблеми теорії та методологї бухгалтерського обліку, контролю і аналізу. 2015. № 3 (33). С. 309-325.

4. Безверхий К. В. Порівняння елементів структури інтегрованої звітності та звіту про управління. Науковий вісник Національної академії статистики, обліку та аудиту : зб. наук. пр. 2019. № 1-2. C. 24-31.

5. Гнедіна К. В., Роднєв Д. В. Звіт про управління: сутність та особливості формування. Сучасні світові тенденцї̈ розвитку інформачійних технологій, економіки і права: зб. матеріалів Міжнар. наук.-практ. конф. ЧІІБІП МНТУ ім. акад. Ю. Бугая (Чернігів, 18 квітня). Чернігів, 2019. С. 79-82.

6. Жиглей I. В. Звіт з управління - складова фінансової, нефінансової чи інтегрованої звітності? Проблеми теорії та методології бухгалтерського обліку, контролю і аналізу. 2019. № 42. С. $18-24$.

7. Ковальова Т. В. Організаційні аспекти формування звіту про управління. Проблеми $i$ перспективи розвитку підприємництвв. 2019. № 57. С. 57-65.

8. IFRS Practice Statement 1 Management Commentary. A framework for presentation. URL: http://eifrs.ifrs.org/eifrs/bnstandards/en/PS01.pdf.

9. Звіт про управління за 2019 рік ПАТ «А/Т тютюнова компанія «В.А.Т. - Прилуки». Офіційний сайт компанії ПАТ «А/Т тютюнова компанія «В.A.T. - Прилуки». URL: http://www.bat.ua/group/sites/bat_alajqw.nsf/vwPagesWebLive/DOAKXLAQ/\$FILE/medMDBPYG GY.pdf?openelement.

10. Звіт про управління за 2019 рік СП «Полтавська газонафтова компанія». Офіційний сайт компанії СП «Полтавська газонафтова компанія». URL: http://www.ppc.net.ua/wpcontent/uploads/2020/05/Report_2020-2-rev.pdf.

11. Звіт про управління за 2019 рік ПАТ ЕК «Чернівціобленерго». Офіційний сайт компанії ПАТ ЕК «Чернівціобленерго». URL: http://www.oblenergo.cv.ua/d/ifile.php?i=1180.

12. Звіт про управління за 2019 рік ПАТ «Запоріжжяобленерго». Офіційний сайт компанії ПАТ «Запоріжжяобленерго». URL: https://www.zoe.com.ua/wp-content/uploads/2019/04/звіт-зуправління-2019-на-сайт.pdf.

13. Звіт про управління за 2019 рік ПрАТ «Укргідроенерго». Офіційний сайт компанії ПрАТ «Укргідроенерго». URL: https:/www.uhe.gov.ua/sites/default/files/public_awareness/202008/UGE_19_ua_web_s_0.pdf.

14. Звіт про управління за 2019 рік КП «Тернопільводоканал». Офіційний сайт компанії КП «Тернопільводоканал». URL: https://www.vodokanal.te.ua/pro-nas/economochnipokazniki/zvity-kerivnyka/item/1815-zvit-pro-upravlinnia-2019.

15. Полякова О. М., Кас П. Ю. Особливості формування і розвитку соціальної відповідальності підприємств в Україні. Вісник економіки транспорту і промисловості. 2010. № 32. С. 284-289.

16. Білявський Г. О., Фурдуй Р. С., Костіков І. Ю. Основи екології : підручник. 3-те вид. Київ : Либідь, 2006. 408 с.

17. Грішнова О. А., Брінцева О. Г. Впровадження екологічної відповідальності в практику менеджменту вітчизняних підприємств. Вісник Київського національного університету ім. Т. Г. Шевченка. 2013. № 10 (151). С. 12-18.

\section{References}

1. Pro bukhgalterskij oblik ta finansovu zvitnist v Ukrayini. [About accounting and financial reporting in Ukraine], Law of Ukraine № 996-XV (of July 16, 1999). Vidomosti Verkhovnoyi Radi Ukrayini - Information of the Verkhovna Rada of Ukraine, (40), art. 365.

2. Pro zatverdzhennya Metodichnikh rekomendaczij zi skladannya zvitu pro upravlinnya. [About the statement of Methodical recommendations on drawing up of the report on management], Order of the Ministry of Finance of Ukraine № 982 (dated December 7, 2018). Balans-Balance, (12-13), p. 10. 
ФІНАНСОВІ РЕСУРСИ: ПРОБЛЕМИ ФОРМУВАННЯ ТА ВИКОРИСТАННЯ

3. Svirko, S. V., Barishnikova, O. M. (2015). Zvitnist stalogo rozvitku yak zasib vidobrazhennya stanu ekonomiko-ekologichnoyi bezpeki pidpriyemstva. [Sustainability reporting as a means of reflecting the state of economic and environmental security of the enterprise]. Problemi teorii ta metodolohii bukhhalterskoho obliku, kontroliu i analizu - Problems of theory and methodology of accounting, control and analysis, (3(33)), pp. 309-325.

4. Bezverkhij, K. V. (2019). Porivnyannya elementiv strukturi integrovanoyi zvitnosti ta zvitu pro upravlinnya. [Comparison of elements of the structure of integrated reporting and management report]. Naukovij visnik Naczionalnoyi akademiyi statistiki, obliku ta auditu - Scientific Bulletin of the National Academy of Statistics, Accounting and Auditing, (1-2), pp. 24-31.

5. Hnedina, K. V., Rodnyev D. V. (2019). Zvit pro upravlinnya: sutnist ta osoblivosti formuvannya. [Management report: the essence and features of formation]. Suchasni svitovi tendentsii rozvitku informatsiinykh tekhnolohii, ekonomiky i prava: zb. materialiv Mizhnar. nauk.-prakt. konf. ChIIBIP MNTU im. akad. Yu. Bugaya-Modern world trends in the development of information technology, economics and law: Coll. materials International. scientific-practical conf. CHIIBIP MNTU them. acad. Yu. Bugaya (pp. 79-82).

6. Zhiglei, I. V. (2019). Zvit $\mathrm{z}$ upravlinnya - skladova finansovoyi, nefinansovoyi chi integrovanoyi zvitnosti? [Is the management report a component of financial, non-financial or integrated reporting?]. Problemi teoriyi ta metodologiyi bukhgalterskogo obliku, kontrolyu i analizu Problems of theory and methodology of accounting, control and analysis, (42), pp. 18-24.

7. Kovalova, T. V. (2019). Organizatsiini aspekty formuvannia zvitu pro upravlinnia [Organizational aspects of forming a management report]. Problemy $i$ perspektyvy rozvitku pidpriiemnytstva - Problems and prospects of entrepreneurship development, (57), pp. 57-65.

8. IFRS Practice Statement 1 Management Commentary. A framework for presentation. http://eifrs.ifrs.org/eifrs/bnstandards/en/PS01.pdf.

9. Zvit pro upravlinnya za 2019 rik PAT «A/T tiutiunova kompaniia «V.A.T. - Priluky» [Management Report for 2019 of PJSC “A/T Tobacco Company“ V.A.T. - Priluki”]. Ofitsiinyi sait kompanii PAT «A/T tiutiunova kompaniia «V.A.T. - Priluky» - Official site of PJSC "A/T tobacco company" V.A.T. - Priluki”. http://www.bat.ua/group/sites/bat_alajqw.nsf/vwPagesWebLive/ DOAKXLAQ/\$FILE/medMDBPYGGY.pdf?openelement.

10. Zvit pro upravlinnia za 2019 rik SP «Poltavska gazonaftova kompaniya» [Management Report for 2019 JV "Poltava Gas and Oil Company"]. Ofitsiinyi sait kompanii SP «Poltavska gazonaftova kompaniya» - Official site of JV "Poltava Gas and Oil Company". http://www.ppc.net.ua/wpcontent/uploads/2020/05/Report_2020-2-rev.pdf.

11. Zvit pro upravlinnia za 2019 rik PAT EK «Chernivczioblenergo» [Management report for 2019 of PJSC EC "Chernivtsioblenergo"]. Ofitsiinyi sait kompaniyi PAT EK «Chernivczioblenergo»Official site of PJSC EC “Chernivtsioblenergo”. http://www.oblenergo.cv.ua/d/ifile.php? $\mathrm{i}=1180$.

12. Zvit pro upravlinnia za 2019 rik PAT «Zaporizhzhyaoblenergo» [Management report for 2019 of PJSC "Zaporizhzhyaoblenergo"]. Ofitsiinyi sait kompaniyi PAT «Zaporizhzhyaoblenergo» - Official site of PJSC "Zaporizhzhyaoblenergo". https://www.zoe.com.ua/wp-content/uploads/2019/04/3віт-зуправління-2019-на-сайт.pdf.

13. Zvit pro upravlinnia za 2019 rik PrAT «Ukrgidroenergo». [Management Report for 2019 of PJSC Ukrhydroenergo]. Ofitsiinyi sait kompaniyi PrAT «Ukrgidroenergo» - Official site of PJSC "Ukrhydroenergo". https://www.uhe.gov.ua/sites/default/files/public_awareness/2020-08/ UGE_19_ua_web_s_0.pdf.

14. Zvit pro upravlinnya za 2019 rik KP «Ternopilvodokanal» [Management report for 2019 of Ternopilvodokanal Municipal Enterprise]. Ofitsiinyi sait kompaniyi KP «Ternopilvodokanal»Official site of KP "Ternopilvodokanal". URL: https://www.vodokanal.te.ua/pro-nas/economochnipokazniki/zvity-kerivnyka/item/1815-zvit-pro-upravlinnia-2019.

15. Polyakova, O. M., Kas, P. Yu. (2010). Osoblyvosti formuvannia i rozvytku sotsialnoi vidpovidalnosti pidpriiemstv $\mathrm{v}$ Ukraini [Features of formation and development of social responsibility of enterprises in Ukraine]. Visnyk ekonomiky transportu i promyslovosti - Bulletin of Transport Economics and Industry, (32), pp. 284-289. 
16. Biliavskii, G. O., Furdui, R. S., Kostikov, I. Yu. (2006). Osnovy ekolohii [Fundamentals of ecology]. $3^{\text {rd }}$ ed. Lybid.

17. Grishnova, O. A., Brinczeva, O. G. (2013). Vprovadzhennya ekologichnoyi vidpovidalnosti $\mathrm{v}$ praktiku menedzhmentu vitchiznyanikh pidpriyemstv. [Introduction of ecological responsibility in the practice of management of domestic enterprises]. Visnyk Kyivskoho natsionalnoho universytetu im. T. G. Shevchenka - Bulletin of Kyiv National University named after T. G. Shevchenko, (10(151)), pp. 12-18.

Гнедіна Катерина Володимирівна - кандидат економічних наук, доцент, доцент кафедри бухгалтерського обліку, оподаткування та аудиту, Національний університет «Чернігівська політехніка» (вул. Шевченка, 95, м. Чернігів, 14035, Україна).

Hnedina Kateryna - PhD in Economics, Associate Professor, Associate Professor of Department of Department of Accounting, Taxation and Auditing, Chernihiv Polytechnic National University (95 Shevchenka Str., 14035 Chernihiv, Ukraine).

E-mail: gkv2015oa@gmail.com

ORCID: http://orcid.org/0000-0001-9471-0932

Нагорний Павло Володимирович - здобувач вищої освіти, Національний університет «Чернігівська політехніка» (вул. Шевченка, 95, м. Чернігів, 14035, Україна).

Nahornyi Pavlo - Applicant for higher education, Chernihiv Polytechnic National University (95 Shevchenka Str., 14035 Chernihiv, Ukraine).

E-mail: inn5665@gmail.com

ORCID: https://orcid.org/0000-0002-8311-2491

Гнедіна К., Нагорний П. Звіт про управління: сутність та особливості формування. Проблеми $і$ перспективи економіки та управління. 2021. № 1(25). С. 134-142. 